\title{
Understanding Social Sustainability in Housing from the Case Study "Wohnen mit uns" in Vienna and Adaptibility to Turkey
} Hatice Kalfaoğlu Hatipoğlu*

\section{Abstract}

The aim of this research paper is to contribute to the design of socially sustainable housing by discussing the significance of social sustainability and assessing this quality according to the determined criterias of social sustainability.

There is a massive construction industry in Turkey, most of which is in the housing sector. These residential areas generally have been built as chaotic mass productions and lack a vision related to social quality. Today, there are significant problems confronting the building sector, such as globalisation, industrialisation, the imbalance between nature and humanity. These problems determine the quality of life we will have in the future. The intention of this paper is to demonstrate more socially orientated housing design, especially in countries such as Turkey in which this aspect is not a real concern in the housing practice according to the perception of author, especially in comparison to Europe.

In order to achieve this goal, this paper first points out the importance of social sustainability in housing within architectural quality. The description and necessity of social sustainability in multi-unit housing
Keywords: Social Sustainability, housing quality, housing evaluation, housing design

*Asst Prof. Dr. Faculty of Architecture, Ankara Yildirim Beyazit University, Ankara, Turkey. E-mail: hhatipoglu@ybu.edu.tr 
have been discussed and the criteria have been determined to evaluate the quality of social sustainability.

An award-winning project in Austria has been chosen as a case study to analyse and perceive social sustainability in residential areas, according to the described criteria. These criteria for assessment and the concrete case study including the emerging phase of the project background provide a guideline for developing housing projects towards social quality in Turkey.

In conclusion a general evaluation of the success of the case study with its background and applicability of this concept to Turkish housing, which is used by middle-class has been discussed.

\section{INTRODUCTION}

There is a rapid increase in housing especially in large cities around the world after industrialisation. This rapid change can be perceived in social life, structures and cities. Technology has started to control people and this has resulted in an increasing imbalance between nature, human and technology.

About 30 years ago, there was a paradigm shift, from "hardsystem thinking" to "soft system thinking" (Kaltenbrunner, 2002). As a result of economic and energy crisis, dismiss of social needs and a city stress on human psychology has arisen. These problems led to the concept of "sustainability". Sustainability, as a widereaching concept, acted as a signifier of public awareness (Kalfaoglu Hatipoglu, 2016b). Sustainability is founded upon a three-column model: ecology, economy and society. It is defined as designing without negative impact of future generations and supplying daily needs as best as possible (Brundtland, 1987). Sustainable housing is high-quality housing and seeks to create a better residential environment and enhance people's lives. Sustainability has to answer the following question: How can sustainable architecture contribute to social needs and requirements better? Focusing only on ecological and economical aspects does not bring a real solution; social quality must also be considered in order to have a liveable future. Social quality contributes to qualified housing, which is a crucial issue to ensure a liveable future for the people.

Housing is more than a place that solves basic human needs such as sleeping, eating etc. It is a place that enhances our lifestyle. Moreover, better social quality of built housing projects improves social interactions. The architecture has the power to change the society in a positive way through better forms of productions related to social quality, especially in residential areas. Thus, this liveable future can be formed through a radical awakeness in terms of social sustainability. 
Social sustainability is an aspect of sustainability and is related to the satisfaction level of the users. In architecture, it encourages communication between people and forms the concept "humancentred" planning. Littig and Griessler describe this concept, as "Social sustainability is a quality of societies. It signifies the nature-society relationships, mediated by work, as well as relationships within the society. Social sustainability is given, if work within a society and the related institutional arrangements which satisfy an extended set of human needs and are shaped in a way that nature and its reproductive claims of social justice, human dignity and participation are full filled."(Littig, 2005) Following this definition, sustainability builds the relationship between nature-society-human in the long term with the aim of improving environmental quality as well as social integration and equality of people. This also contributes to their participation, life enhancement, emotional and physical well-being. To achieve these aims meeting the people's requirements is needed. This means social sustainability also emphasizes functional quality as well as social quality. Functionality is described as "the quality of having a practical use: the quality of being functional and the particular use of set of uses for which something is designed".("Functionality," n.d.) The people must be able to feel comfortable, healthy and safe in their houses, which defines the "optimal circumstances" (not too hot/cold/dirty/dark/noisy). The houses need to be capable of providing privacy, social contact, freedom, choice and autonomy.

\section{METHODOLOGY}

To assess the qualities of social sustainability in residential areas, which is a leading aspect of the liveability of a place, the criteria of social sustainability was determined. These criteria contributing to the social quality provide the possibility for the evaluation of social sustainability of several housing projects.

A case study has been chosen from Vienna, which has an award of "State Award Architecture and Sustainability", to understand these aspects more concretely. Vienna has been nominated the most liveable city in the world eight times and has managed to take several important measures in terms of social quality to offer liveable, equal and sustainable spaces politically as well as practically. ("Vienna voted the most livable city in the World for the eight time!,"). Therefore analysing a case study from Vienna is insightfull and important. This case study is the housing "Wohnen mit uns" by Einszueins Architecture Office. This building comes into prominence especially with its participation and integration possibilities for the tenants, and is a product of many years' 
experience of sustainable and good quality social housing in Austria.

This case study is analysed according to the principals of criteria of social quality, defined in the following section. Qualitative analyses including spatial and structural data has been used with observations, floor plans and sections obtained from the Einszueins architecture office. Presentations of the housing and interviews with the architects are the other data used for the analysis of the criteria.

\section{INDICATORS OF SUSTAINABILITY}

The main point of view of social sustainability is a humancentered planning which means taking the needs and requirements of the user to the center with a balance with nature. There are some aspects, which should be considered in the residential design to provide this goal.

The criteria of social sustainability related to the social functional quality has been adapted from the Social Functional Quality Analysis of "Sustainable Housing Quality (SHQ)" Framework (Kalfaoglu Hatipoglu, 2016b), which was developed to evaluate housing quality in a holistic view. The principals of the SFQA of this framework have been used to analyse the following case study in this paper. The indicators of social sustainability are determined as:

1. Needs-oriented design and participation

2. Accessibiltiy and circulation

3. Efficiency of planning

4. Flexibility

5. Safety

6. Health, well-being and comfort

7. Common rooms and facilities

8. Open spaces

9. Children's playground

10. Proportion of buildings, diversity of living units

11. Storage, parking and waste services 


\section{CASE STUDY “WOHNEN MIT UNS (LIVING WITH US)}

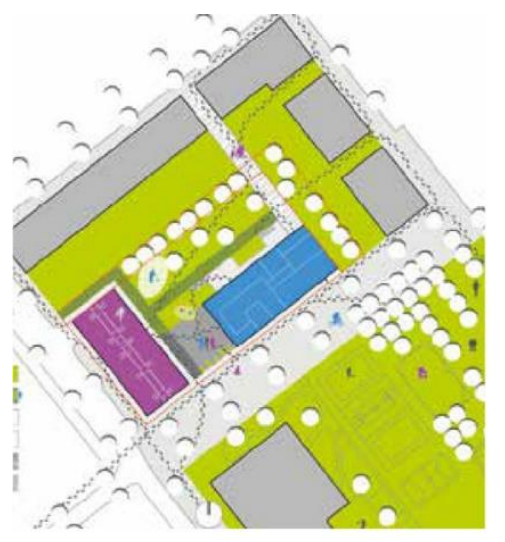

Figure 1. Site Plan (Schönfeld, 2012)

This project, winner of the "State Award Architecture and Sustainability 2014", was built following a housing developer competition ("Bauträgerwettbewerb" in German). On this site (Figure 1) there are two building blocks, which were designed by different architecture offices. These are "Wohnen mit uns (living with us)" and "Wohnen mit Scharf". These two buildings have different concepts but similar constructions and seem in harmony without copying one another, which contributes to architectural quality. The block, named "Wohnen mit Scharf", emphasizes individual and intergenerational functionality. Besides, it qualifies for super subsidies from the City of Vienna that enables easy participation of the tenants in the project, mainly tenants with an immigration background. On the other hand, the case study project "wohnen mit uns" focuses on communication and participation and also subsidied by the City of Vienna. Housing Project Vienna, Association for a Sustainable Life, composed the idea and concept of the project. Feldmann, the initiator of the project, tells the beginning of idea as follows: "We sent an e-mail to the group with a question: How can we live well in a social community life while reducing our $\mathrm{CO} 2$ emissions and our ecological footprint, and how can we create it in an urban environment?" ("Ein Weiter Schritt über Technische Werte Hinaus, Wohnhaus Wohnprojekt Wien, Wien Leopoldstadt," 2014). This concept encouraged people to develop these aims: living together in their own properties with their selfmanagement. Some other sustainable concepts have emerged, such as "car sharing" and communal participation. Instead of a garage in the basement, a place for rent a car and different common rooms are designed. On the ground floor and top floor, there are some other common rooms to promote communication between inhabitants. 
Figure 2. Wohnen mit Uns, garden (Einszueins Arch. Office Documents)

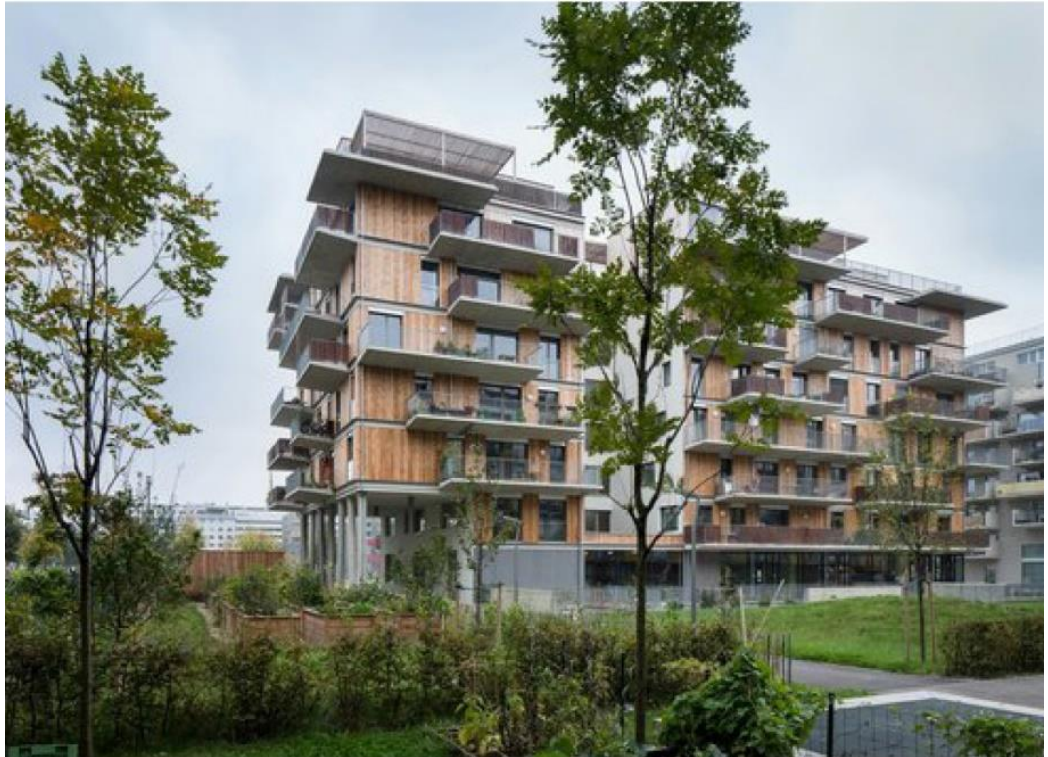

The goals of this project are; participation, self-management and living sustainability and the main concerns of the architects are to promote solidarity and connection to life, to ensure communication through common rooms, liveable spaces and cities. It has been considered a planning process with structural concepts, innovative methods and the ideas of tenants to provide a high level of participation, which was very intensive and deliberate. It is vital to understand the diverse needs of residents, as there are not any standard families and this participation process transforms inhabitants from victims to participants (Bayer, 2015b).

\section{Project Analysis Regarding Social Sustainability}

\section{Needs-Oriented Design and Participation:}

Affordability and needs-oriented design are important criteria in the planning phase. Due to the participation of the residents, the housing meets the needs perfectly. "A sustainable home with a good neighbourhood and communication in the urban life" has been the main challenge of this project.

To ensure participation, several meetings were organized to inform people and to determine needs related to their dwelling design. This allowed them to discuss about the room organisations of the house plan. Additionally, 3D models were created to visualize understandable projections of the dwellings.

At the beginning of the participation process, some questionnaires were prepared. Besides the questionnaires, information about the storeys of the flats they choose, the characteristic of each floor and direction of the flats have been described. Figure 5 shows one of the questionnaires conducted in the meetings, which includes 
Understanding Social Sustainability in Housing from the Case Study "Wohnen mit Uns" in Vienna and Adaptibility to Turkey

questions about the room sizes and numbers each resident need. Figure 3 and 4 show workshops organised for participation to determine a layout for community spaces and dwelling decisions.

As a result, it can be stated that participation, which is an important issue to understand different needs and requirements of the users, has been one of the central concerns in this project. Each dwelling has a different character due to the orientation of its own user, which is a good example for participation and needoriented design.
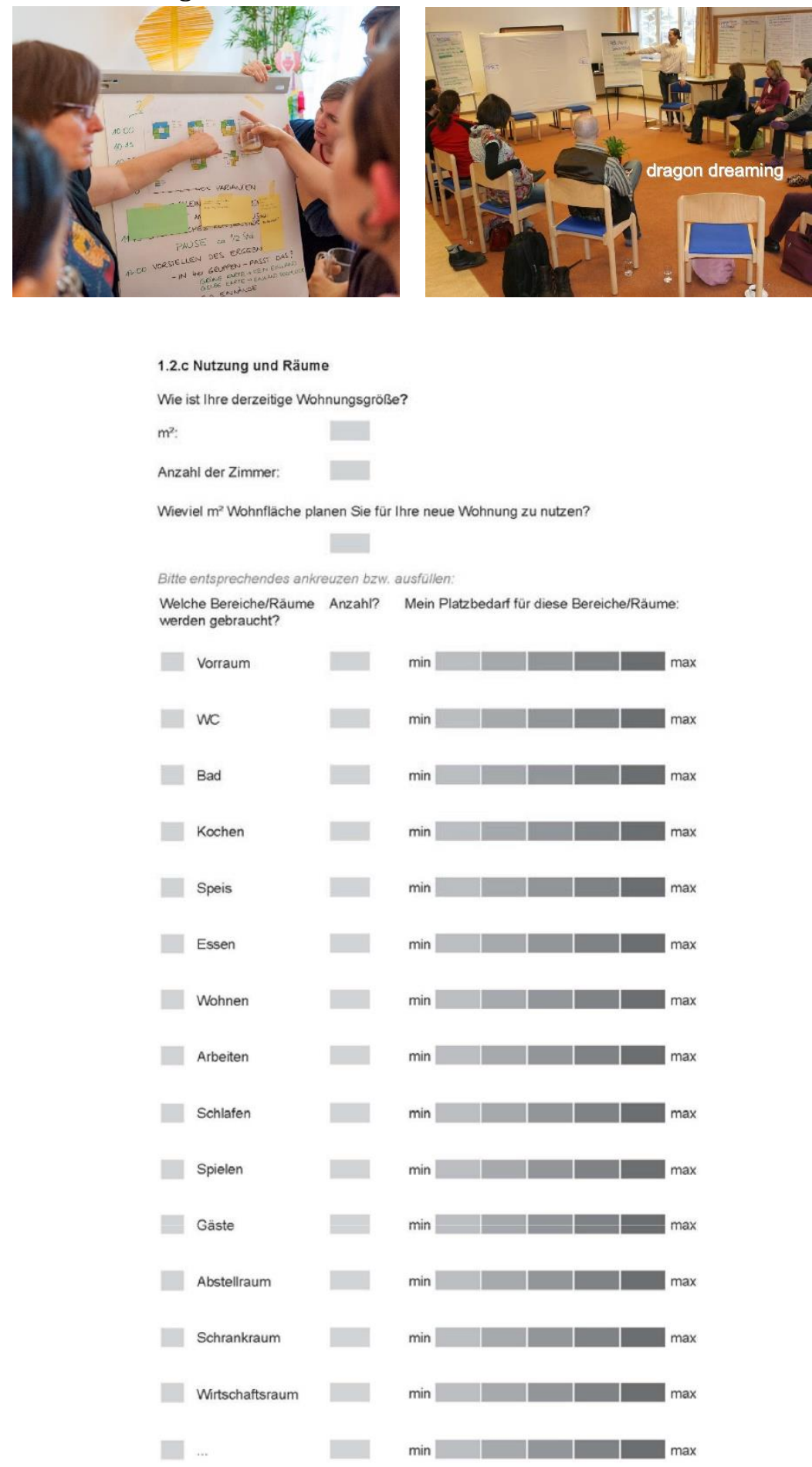

Figure 3. (left) Workshop organised for participation, (Bayer, 2015a)

Figure 4. (right) Seminar organised for participation (Zilker Presentation in Bratislava, Einszueins Arch.Office Documents)
Figure 5. Questionnaire (Bayer, 2015a) 


\section{Accessibility and Circulation:}

Accessibility is to reach the desired destination without any difficulty and to take part in their intended activities (Van der Voordt, 2005). There is a clear and adequate movement concept in and around the building. The entrance of the building has a familiar atmosphere with its wide space, information boards and diagrams that give information about the building services. A play equipment has been located to enrich this familiar atmosphere and attractiveness. The circulation routes in the building get rich daylight that supports the safety of pedestrians and have an adequate atmosphere, which also contributes neighbourhood (Figure 6). Descriptive and contrary architectural elements and materials have been applied to provide an efficient orientation. Necessary numbers and names are clear, visible, and legible for the ease of use.

The planning considers pedestrians, especially people with impaired mobility, children, and old people as well as cyclists. Important measures were taken from the design phase to support wheeled equipment for disabilities and prams, which support "design for all" concept. That means all people are able to use services equally and independently. Bicycle using is encouraged through wide storage rooms for bicycles and the adequate environmental design around the site. Vehicle flow has been minimised through a car sharing system and the absence of an individual parking place.

Figure 6. Photos from circulation routes (photos by the author)
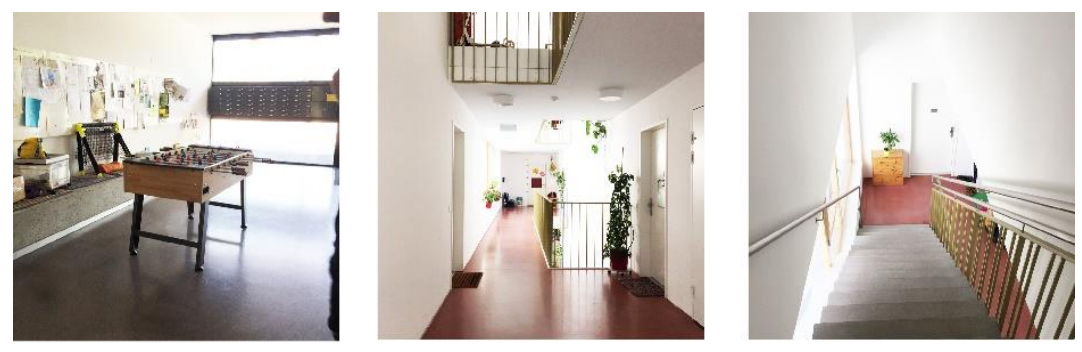

\section{Efficiency of Planning:}

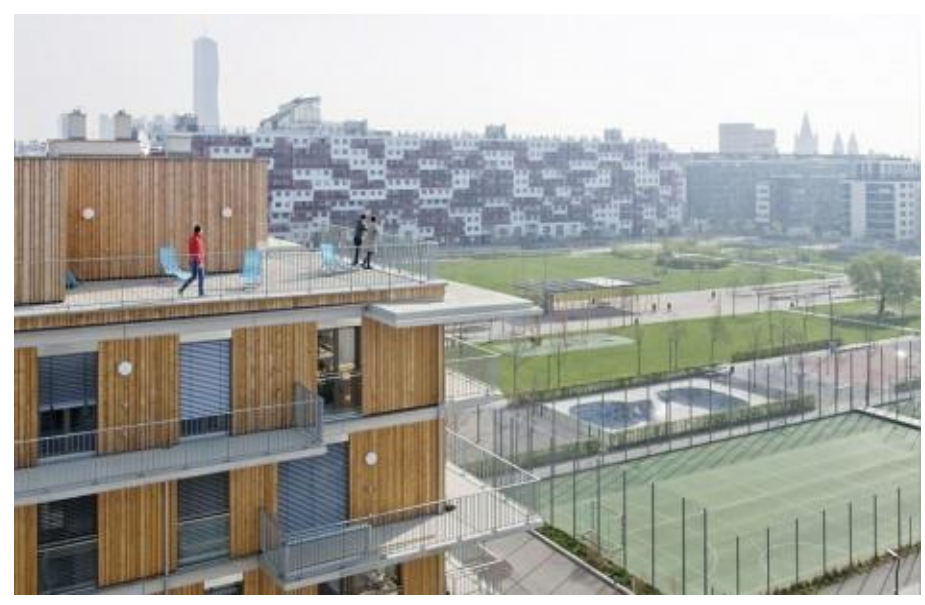

Figure 7. View to the Bednarpark (Einszueins Arch.Office Documents) 
Efficiency of planning means appropriate solutions and organisations of a space. The site is appropriate for residential use, as the area around the building site has also been designed through competitions and there was to promote a liveable residential area in the city life with its greenery and public transport possibilities which discourage traffic flow.

The design in total has certain challenges and goals, which provides a sustainable, family-orientated neighbourhood in the city. These intentions make this planning more efficient. Participation and ecological concerns have been focused to create a liveable housing estate. The ambiance of corridors in the apartment ensures a wide and relaxing space with the contribution of greenery from inhabitants. Sufficient capacity for individual rooms in the planning has been considered parallel to the requirements of the users. Common rooms have connections to open spaces and outdoor facilities, which provide a link to the nature as well as between themselves. A sunken courtyard has been planned at the rear of the building to create light for the underground functions, which also creates a more attractively designed space for the inhabitants. As a result optimum solutions have been decided through the efficient planning process.

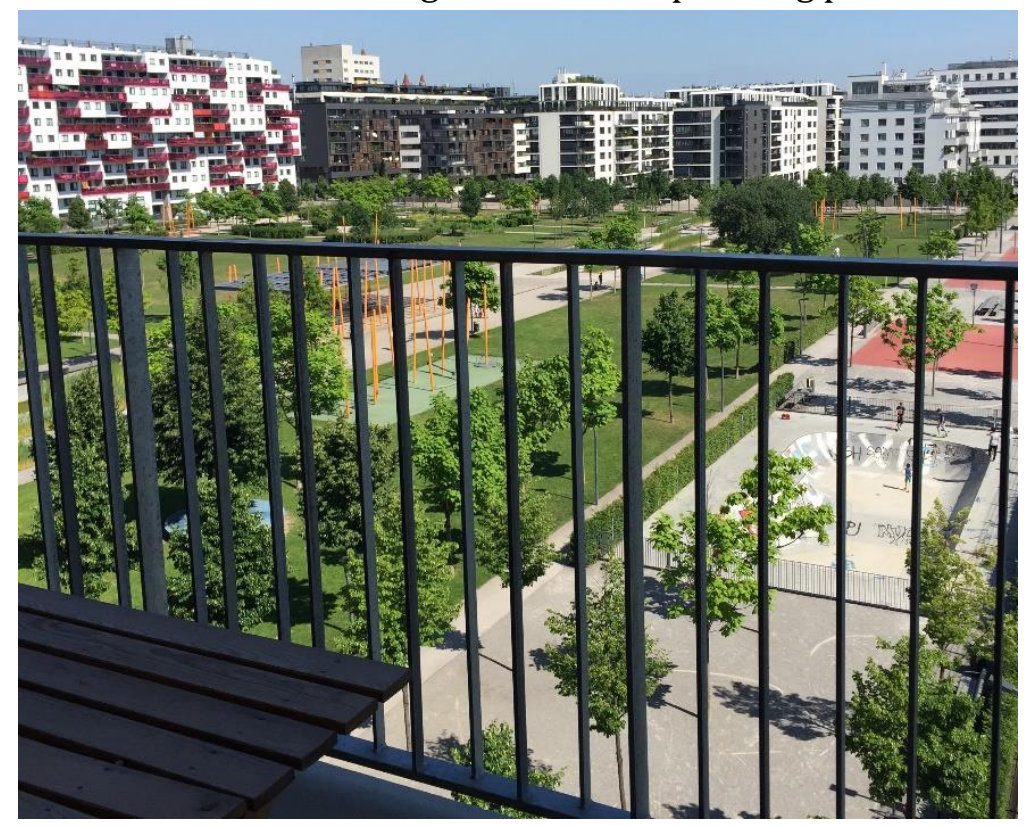

\section{Flexibility:}

Despite the detailed participation process, it has been considered that the needs of the inhabitants may have changed within the time through the alteration of economic and social circumstances, which requires flexible space organisations or some design arrangements to ensure flexibility have been discussed in the planning phase of the project. Interior dividing walls are non-load bearing in order to be adaptable for different solutions. The entrances of the dwellings also provide the possibility to combine

Figure 8. View from the roof floor WMU (photo by the author) 
two dwellings, or to divide a large dwelling to two. Figure 9 shows the flexibility concept and demonstrates that the entrance doors of the dwellings, size and place of windows and balconies are flexible.

Figure 9. Flexibility Diagrams (Einszueins Arch. Office Documents)

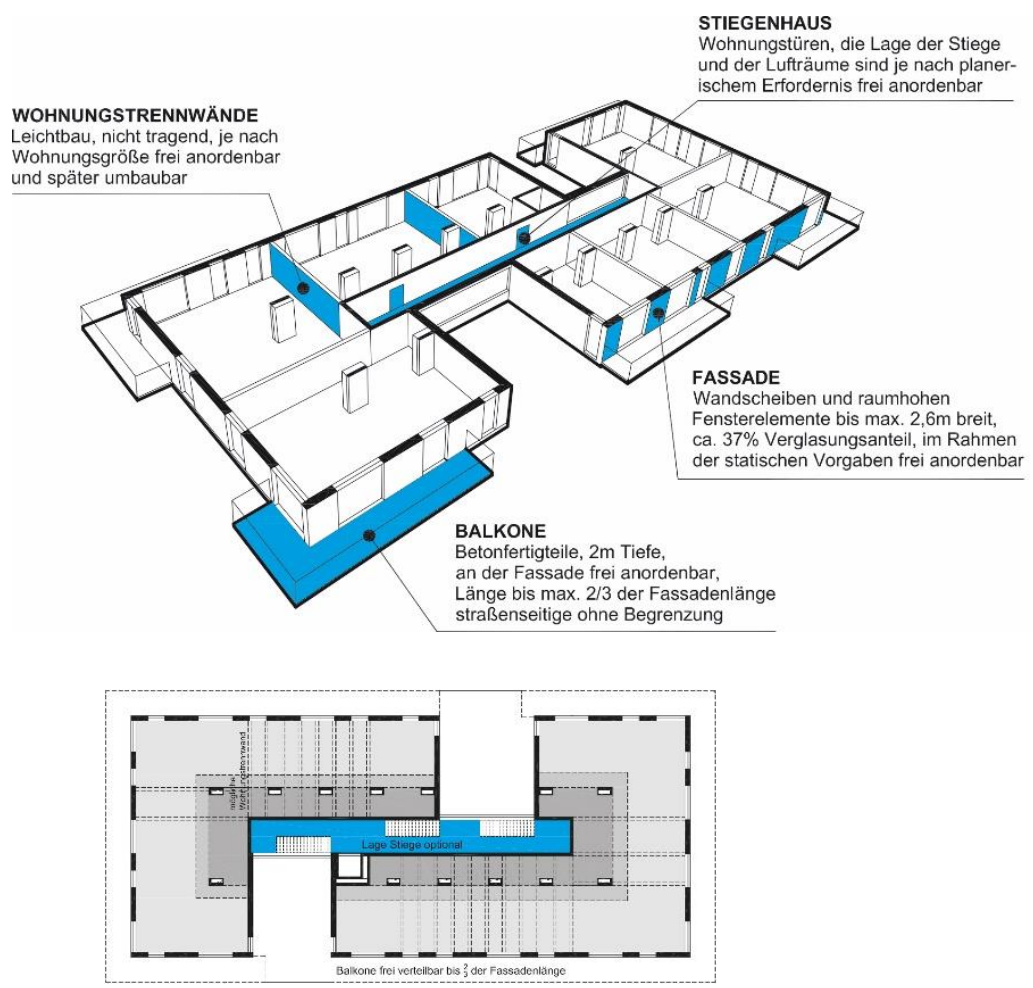

Safety:

The building site is not enclosed with guidance outside but this is an advantage, as the site is not designed like a closed ghetto. The safety of the building is ensured with controlled access at the entrance. Public areas are overlooked and controlled to anticipate possible dangers.

The safe transportation of people and goods are ensured by preventing the possibility of falls through non-slip floor finishes, providing adequate lighting for corridors and vertical circulation routes. Precautions have been provided to prevent fire outbreak and provide safe escape through fire-resistant materials. Moreover safety glass is used instead of ordinary glass.

\section{Health, Well-being and Comfort:}

Since the built environment has an effect on psychology, wellbeing, opportunities for social interaction and can cause a physical illness known as the "Sick Building Syndrome" (Rosner, 2007), it is essential to consider this criteria in residential design. These illnesses can be prevented through designing healthy living environments and encouraging healthy lifestyles by creating spaces for communication, activities for hobbies like gardening, walking cycling, relaxation etc. and these factors are considered in 
Understanding Social Sustainability in Housing from the Case Study "Wohnen mit Uns" in Vienna and Adaptibility to Turkey

this housing. Psychological well-being of people is supported through the atmosphere inside and outside of the building through common rooms, sitting areas, as well as greenery at the top of the building and in the garden. Moreover they can garden in their garden plots (also together with neighbours) both in the ground-floor garden and on the roof. Sauna and meditation room contribute to enrich well-being and comfort.
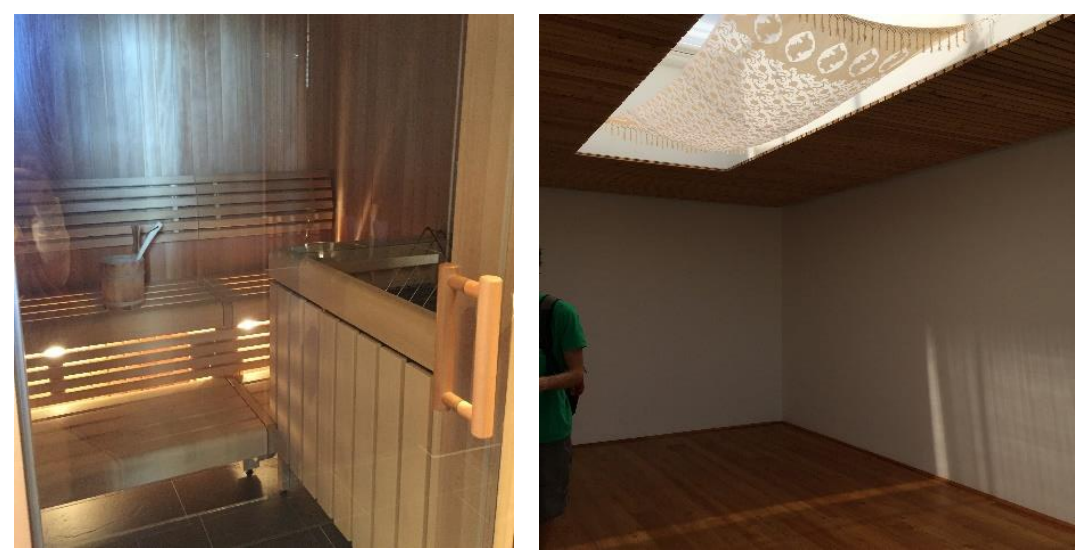

Because of the discouragement of car use, this site is isolated from main traffic roads, which prevent possible noises from vehicles. This has transformed the area a liveable atmosphere.
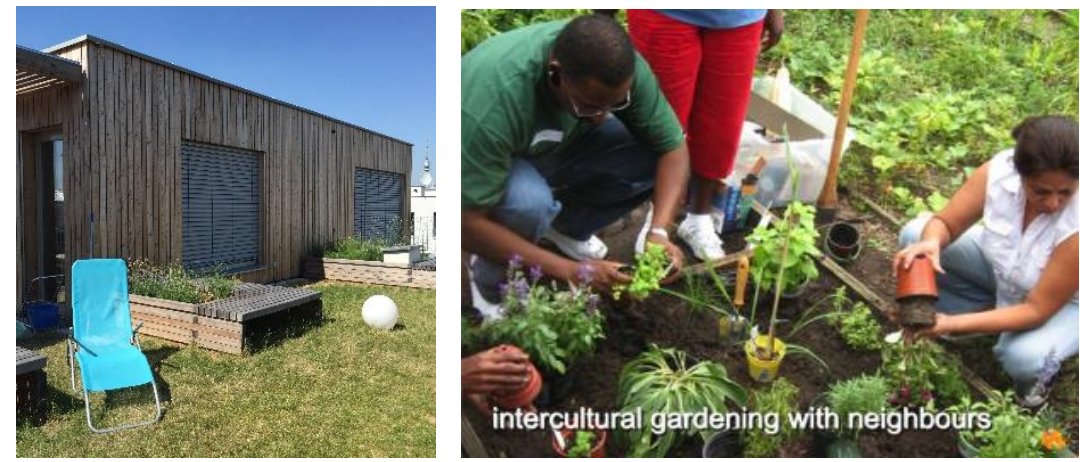

To avoid negative effects of uncomfortable living spaces sound insulation between different units and against outside should be implemented to avoid unwanted noise. In this project, sound insulation of walls, ceiling and windows have been applied adequately, which is also obligatory by building norms in Austria. Noisy communal eqipments such as lift etc. are placed to be more than $3 \mathrm{~m}$ distance from doors and windows of the dwelling. The rooms and circulation routes reach good daylight and have the possibility of natural ventilation for the comfort of the residents.

\section{Common Rooms and Facilities:}

People need indoor spaces by means of communication and freetime activities, which enhance the quality of life and attractiveness of residential areas. The building has a hybrid function to serve as a housing within $350 \mathrm{~m} 2$ commercial uses, common rooms for
Figure 10. Sauna (left), meditation room (right). (photos by the author)

Figure 11. Left to right; Roof Garden (by the author) and intercultural gardening with neighbours, (Bayer, K.2015B) 
Figure 12. Diagram showing community rooms and facilities (Einszueins Arch. Office Documents) communication. The eight residents of the housing complex manage a grocery store with cafe including natural products, which is compatible with the sustainability concept of the building. The architects of the building have also their office and dwelling in the building.

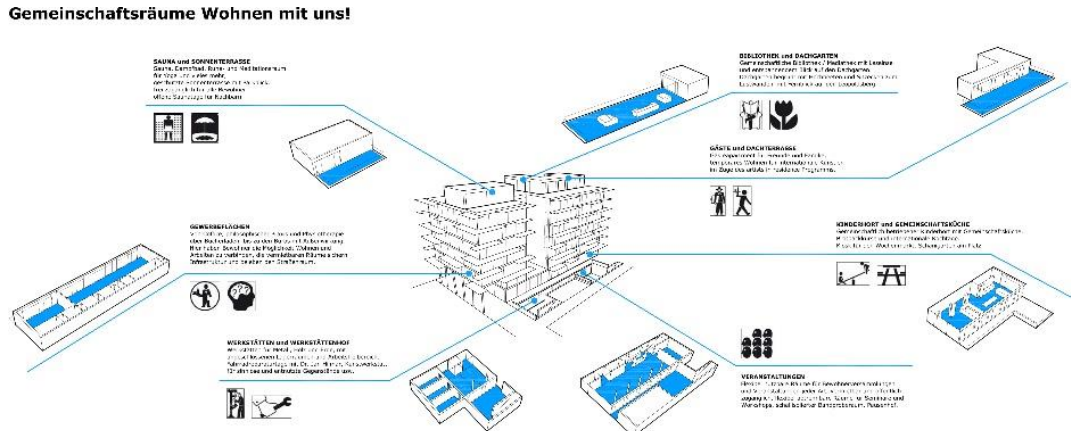

The building has a great quantity of community rooms, which occupies $700 \mathrm{~m} 2$ area. These are in the basement floor which occupies the space instead of an underground car-park and gets very good light through the sunken courtyard at the back of the building, on the ground and top floor. These community rooms are equal to $25 \%$ of the total floor area of the building. The access to these rooms and the link of these rooms to the surrounding are designed to provide an ease of use for the inhabitants. These rooms are enriched with visual contacts and spatial scope. At the underground floor there is a multifunctional event room with size of $200 \mathrm{~m}^{2}$, which has a direct access to the garden through the courtyard. The architect of the project indicates that there are 6-8 events per week such as celebrations, theatres, workshops, concerts, and presentations some of which are also open to the external users. Next to the entrance is the common kitchen on the ground floor, which is very efficiently equipped. Two cooking places with double equipment and a dining room for about 30 people serve to the inhabitants and people at offices. There is a team for cooking who are volunteers from the inhabitants. The meals cost 3 euros each. Architect Bayer states in her presentation that one of the inhabitants (Elisabeth) says, “...cook once, eat 10 times. Lunch organisation in this project facilitated my life and enriched my day with my child." (Bayer, 2015a) Next to the kitchen is the indoor playground with a visual contact to the kitchen and to the event room at the lower floor through a glass wall. Zilker, who is one of the architects and also a resident states this concept as: "I have always dreamt of a place where I can see my children but I don't hear them. Thus, a glass wall allows the children to be seen by the families in the events room from the kitchen."(Zilker, 2015) 


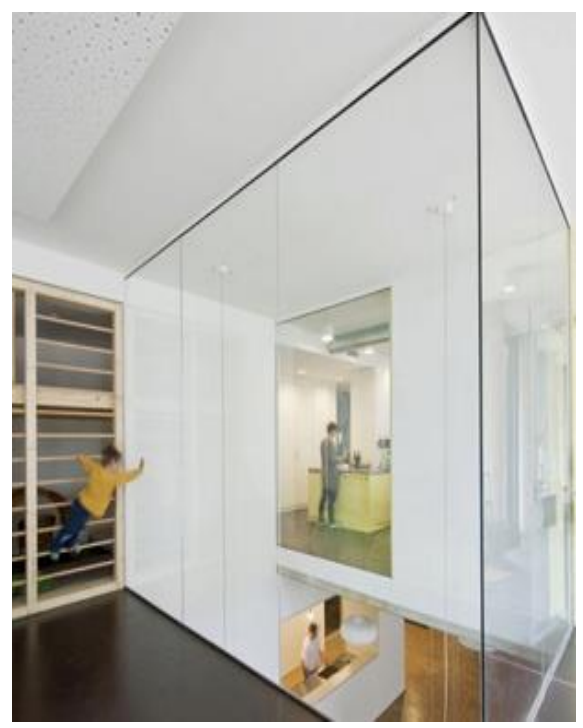

Figure 13. Connection between Kitchen and Playground (Einszueins Arch. Office Documents)

The housing has an atelier, which includes tools and allows people to have a hobby as a relaxing activity. The furniture of the guest apartments on the top floor was made in this atelier by the people who have an interest. This proves the success of idea of communal engagement and solidarity, which was one of the aims of the initiators of the project and ensured by their architectural design concepts.

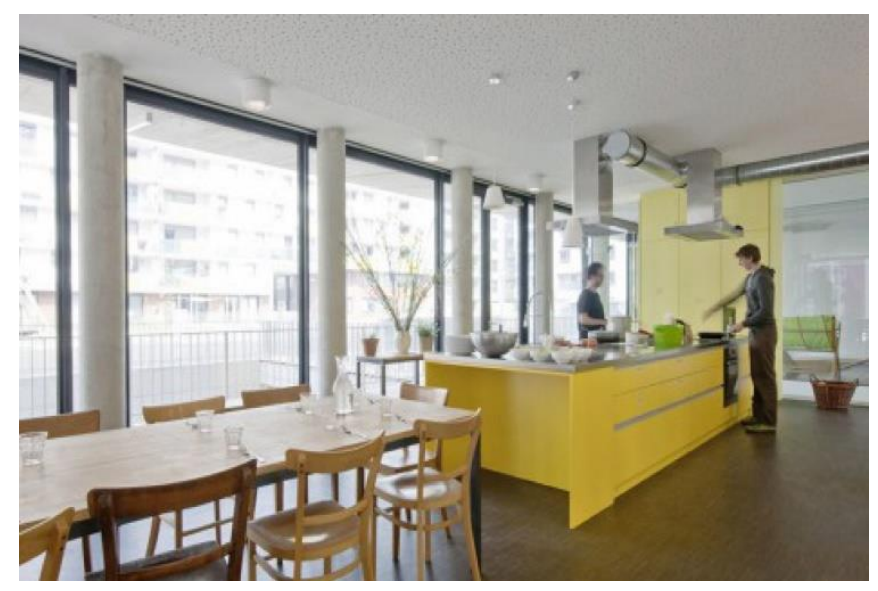

Figure 14. Common kitchen (Einszueins Arch. Office Documents)

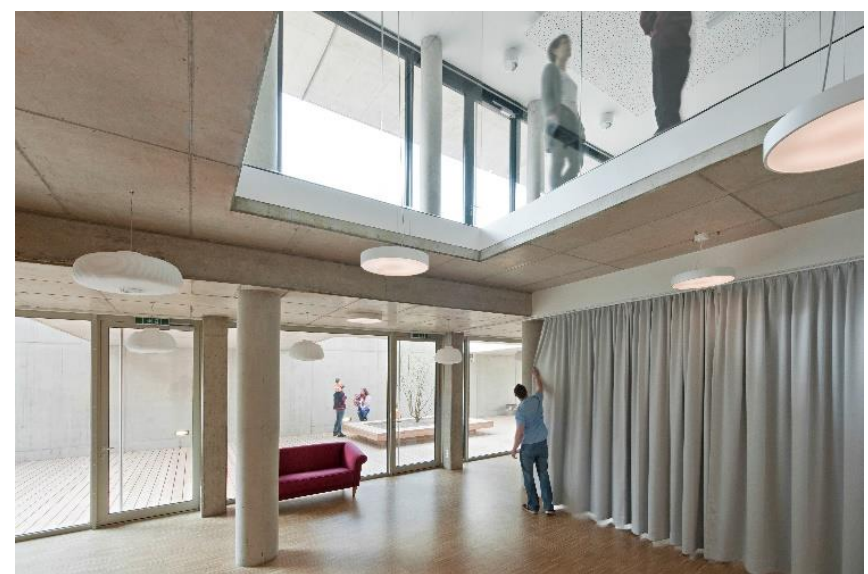

Figure 15. Multifuncitonal room (Einszueins Arch. Office Documents) 
Instead of private units at the top floor, which is assumed as the best and most desired location of the buildings in Austria, there are three guest rooms, yoga and meditation room, sauna and a library including donated books and a panorama view to Bednar Park in front of the housing.

Figure 16. Top left; rehearsal room, top right; interactions between the rooms, bottom; library, a view to the window of the library (Photos by the author)

Figure 17. Sizes of the open space and community rooms in relation to dwelling area (by the author)

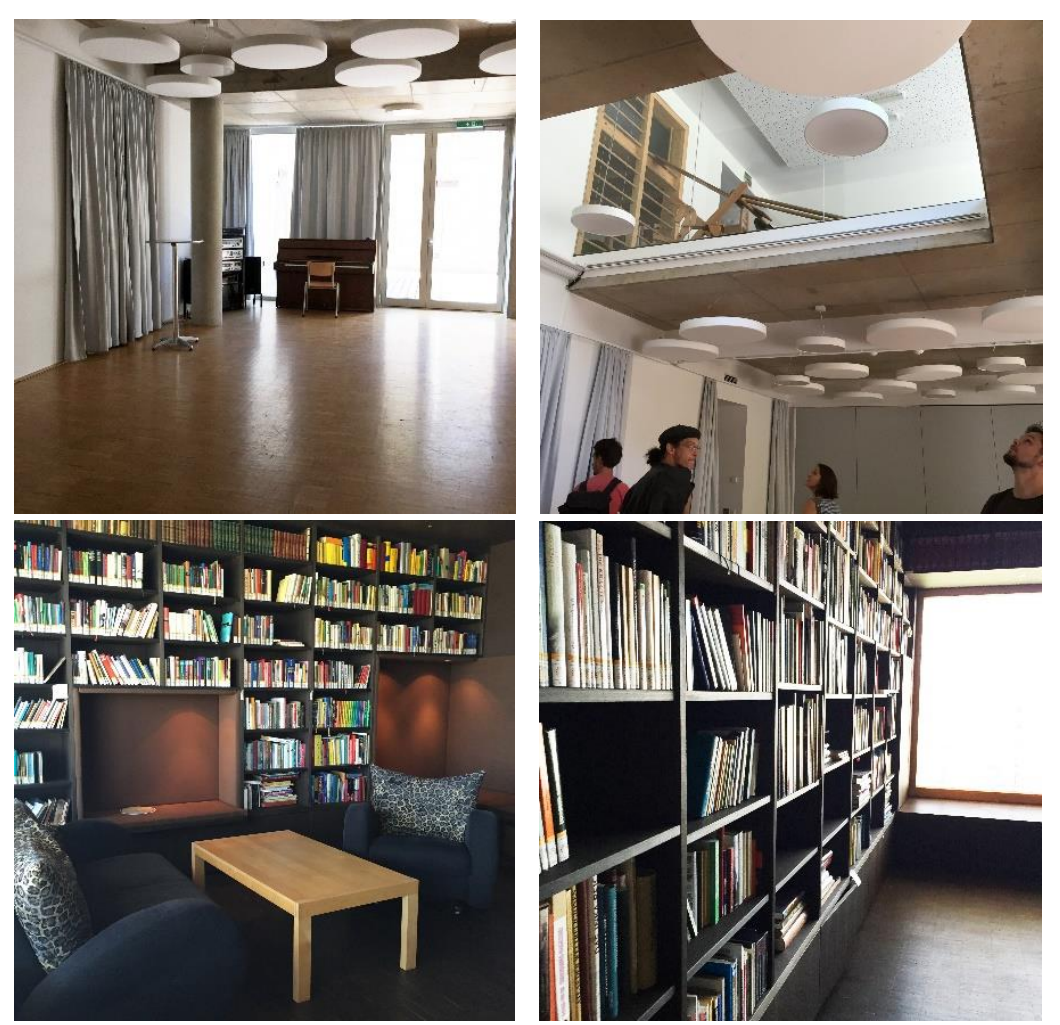

\begin{tabular}{|c|c|c|c|c|}
\hline TOTAL STTEAREA & \multirow{2}{*}{ TOTAL DWELLING AREA } & $\begin{array}{c}\text { COMMUNIT ROOMS } \\
\text { WMU + WMS" }\end{array}$ & $\begin{array}{l}\text { OPEN SPACE } \\
\text { incl. common terraces and }\end{array}$ & TOTAL NUMBER OF DWELLING \\
\hline $4783 \mathrm{~m} 2$ & $7200 \mathrm{~m} 2$ & $773,18 \mathrm{~m} 2$ & 3772 & 90 \\
\hline
\end{tabular}

"WMU: Wohnen mit uns, WMS: Wohnen mit Schar

\section{Open Spaces:}

Being a part of nature is important in today's city life because with rapid urbanisation, buildings are the dominant features of cities, which encourages an egocentric approach to life. Thus people feel the need of open spaces in their housing environment and want to be a part of the nature in their stressful urban life. These open spaces are visually stimulating as well as provide opportunities for community.

The garden and sunken courtyardt of the building allows play, recreation, celebration and gardening. A part of the garden has been designed to provide plots for growing plants and vegetables by the tenants, which ensures a relaxing hobby for them (Figure $11,19)$. In order to support urban coherence the harmony between the garden design and Rudolf-Bednar Park in front of the building has been a consideration in the design phase. The 
Understanding Social Sustainability in Housing from the Case Study "Wohnen mit Uns" in Vienna and Adaptibility to Turkey

courtyard allowing light into the common rooms in the basement floor serves as an extra-enriched place for community and play for the children (Figure 18). It is also required for a landscape architect to contribute to the landscape design as an obligatory part of the competition.
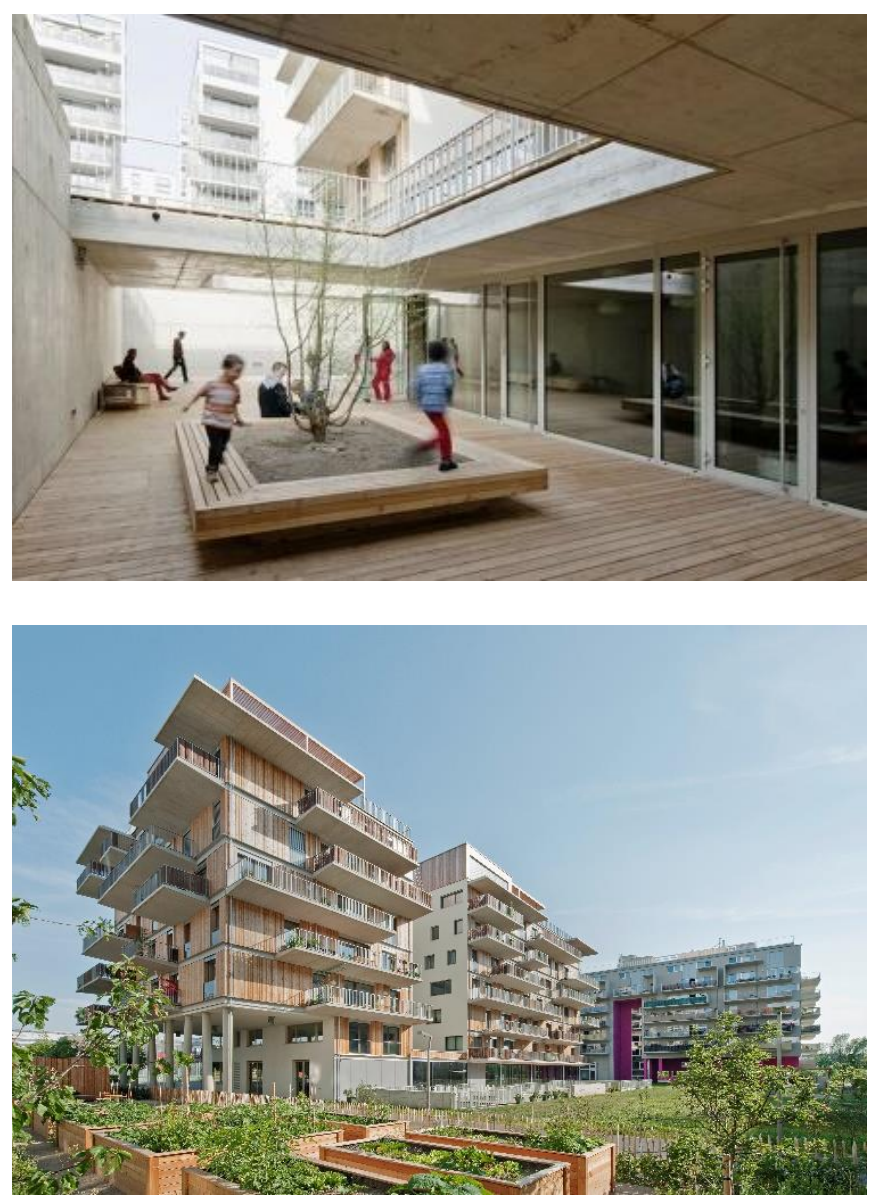

Another common open space is the roof terrace located at the top floor with the possibility of a sunbath. This green-planted roof garden is near to the library and sauna/meditation room and moreover includes some raised flower beds (Figure 20). The materials of the common open space are natural such as wood and the general appearance of these spaces is natural and green.

Residents have balconies as private open spaces designed with materials that allow taking advantage of the view and fresh air. These have standard depth of two meters and range in size between $10 \mathrm{~m}^{2}$ and $18 \mathrm{~m}^{2}$, which is chosen by the user according to their requirements. The maisonettes of the other building (Wohnen mit scharf, which is designed together in the competition) have their own roof terraces.
Figure 18. Sinken Courtyard (Einszueins Arch.Office Documents)

Figure 19. The rear garden with gardening pots (Einszueins Arch.Office Documents) 
Figure 20. Top left; garden, top right; roof garden, bottom left; balcony of a dwelling and bottom right; the sight of balconies from the front of the building (Photos by the author)
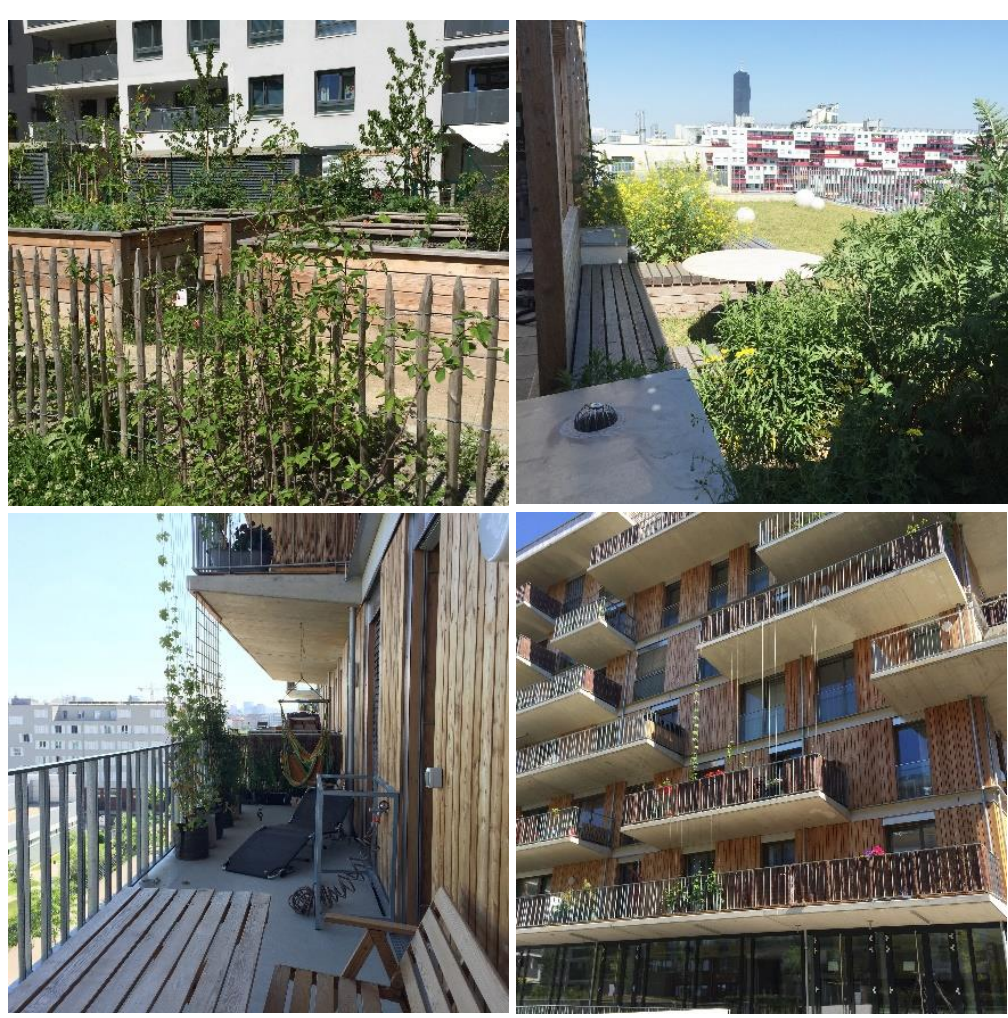

\section{Proportion of Buildings and Diversity of Living Units:}

Today there is a shift to high buildings due to the density of urban structures. There are advantages of this transformation but also the disadvantages cannot be ignored. The problem of connection between interior and exterior and the negative effect of height difference and density on communication between people are some of these disadvantages. Jan analyses that the people in higher floors have less communication possibilities than the people in lower floors (Gehl, 1987). There are some studies that indicate children in high rise dwellings are more socially deprived than neighbourhood peers than low storey buildings (Alexander, 1977).

The proportion of the building is in harmony with the surroundings and convenient as human scale for a residential area with its eight floors (including the roof storey). This allows people to be a part of the urban scene from their dwellings and they do not lose sight of the city perspective and details. Moreover, this proportion allows stair use in vertical circulation independent from lift usage, which is also encouraged with its attractive character including openings in the ceiling that creates an enjoyable space movement.

There are a variety of different living options, which is important for the quality of the housing. There are several different apartment types from 36 to 137 square metres in the housing (only in Wohnen mit uns). There are 39 dwellings each of which 
Understanding Social Sustainability in Housing from the Case Study "Wohnen mit Uns" in Vienna and Adaptibility to Turkey

has a different floor plan (Figure 21, 22). These different types offer also several room divisions according to the personal needs and requirements of participants through the flexible structure system with non-load bearing interior walls. The other building, "Wohnen mit Scharf" have also different types, which vary in size from 54 to 119 square metres some of which are area maisonettes with roof gardens. This variety of dwelling types encourages the integration and communication of people from different ages and backgrounds.

WOHNEN MT SCHARF

\begin{tabular}{|c|c|c|c|c|c|c|c|c|c|c|}
\hline BLOCK TYPE & $\begin{array}{l}\text { NUMBER OF } \\
\text { STOREY INC. } \\
\text { GROUND FL. }\end{array}$ & \begin{tabular}{|l|l} 
NUMBER OF \\
DWELING \\
TYPEB WWTH \\
2ROOMS \\
\end{tabular} & \begin{tabular}{|l|l} 
NUMBER OF \\
DWELLING \\
TYPEC WWTH \\
3ROOMS \\
\end{tabular} & $\begin{array}{l}\text { MAISONETTE } \\
\text { TYPE } 1 \\
73,46 \mathrm{~m} 2\end{array}$ & $\begin{array}{l}\text { MAIISONETTE } \\
\text { TYPE } 2 \\
97-100 \mathrm{~m} 2\end{array}$ & $\begin{array}{l}\text { MAISONETTE } \\
\text { TYPE } 3 \\
\text { more than } 100 \mathrm{~m} 2\end{array}$ & $\begin{array}{l}\text { DWELLING } \\
\text { WWH } \\
\text { ROOF-TERRACE }\end{array}$ & \begin{tabular}{|l} 
TOTAL \\
NUMBER \\
OF \\
BLOCKS
\end{tabular} & $\begin{array}{l}\text { NUMBEER OF } \\
\text { DWELLINGS } \\
\text { IN OOE BLOCK }\end{array}$ & \begin{tabular}{|l|}
$\begin{array}{l}\text { TOTAL } \\
\text { NUBBER } \\
\text { OF } \\
\text { DWELLINGS }\end{array}$ \\
\end{tabular} \\
\hline $\begin{array}{l}\text { WOHNEN } \\
\text { MIT } \\
\text { SCHARR }\end{array}$ & 8 & 19 & 22 & 1 & 4 & 5 & 4 & 1 & 51 & 51 \\
\hline
\end{tabular}

\begin{tabular}{|c|c|c|c|c|c|}
\hline BLOCK TYPE & $\begin{array}{l}\text { EACH DWELLING HAS A DIFFERENT PLAN } \\
\text { DUE TO THE PARTICPATION }\end{array}$ & \begin{tabular}{|l|} 
GUEST \\
APARTMENTS \\
ATROOF \\
FLLOR
\end{tabular} & \begin{tabular}{|l} 
TOTAL \\
NUMBER \\
OF \\
BLOCKS
\end{tabular} & \begin{tabular}{|l} 
NUMBER OF \\
DWELINGS \\
IN ONE BLOCK
\end{tabular} & \begin{tabular}{|l|} 
TOTAL \\
NUBBER \\
OF \\
DWELLINGE
\end{tabular} \\
\hline $\begin{array}{l}\text { WOHNEN } \\
\text { MIT } \\
\text { UNS }\end{array}$ & 39 & 3 & 1 & 39 & 39 \\
\hline
\end{tabular}
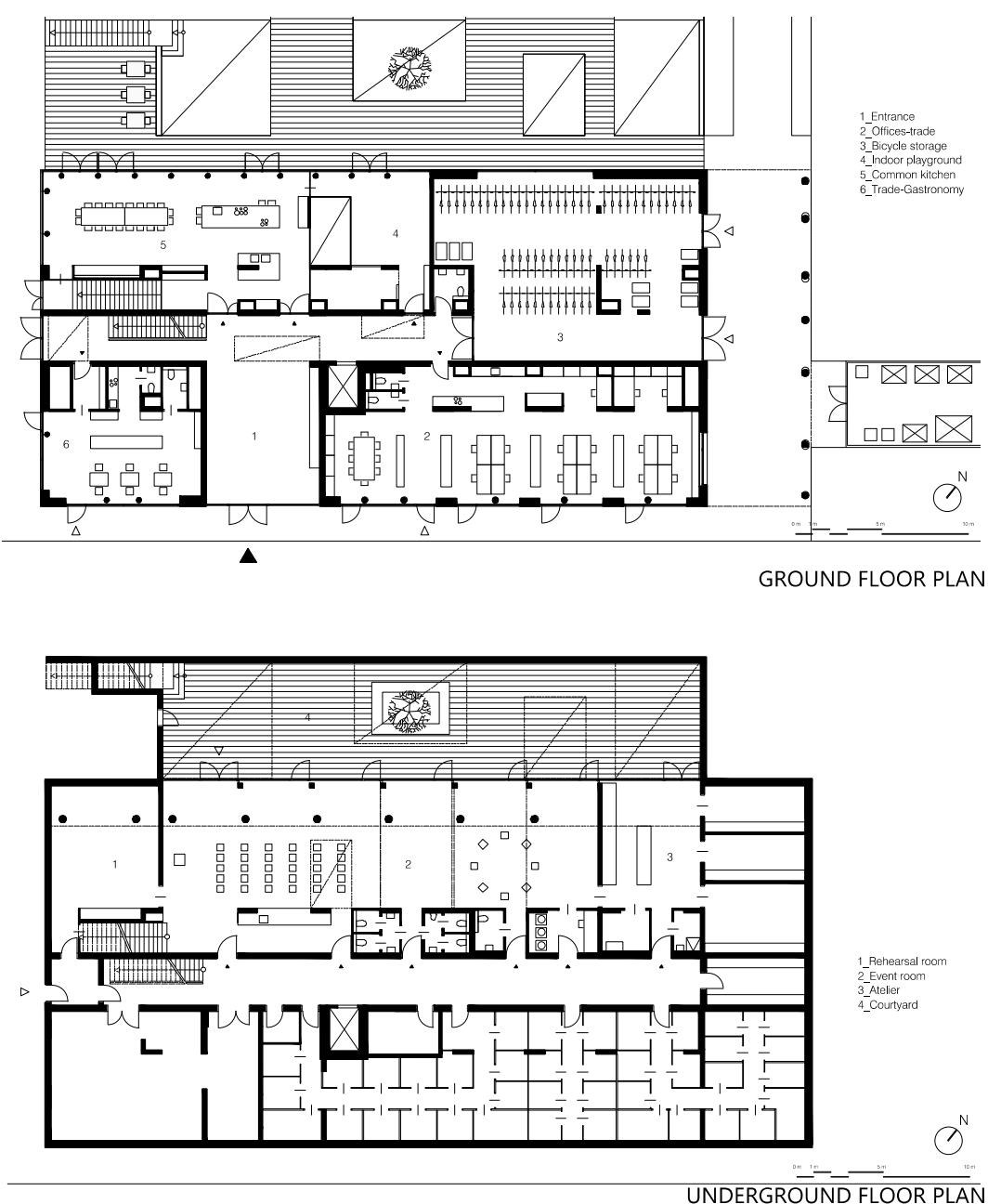

Figure 21. Diversity of living units "Wohnen mit uns" and "Wohnen mit Scharf" (by the author)

Figure 22. Floor plans (Einszueins Arch.Office Documents) 

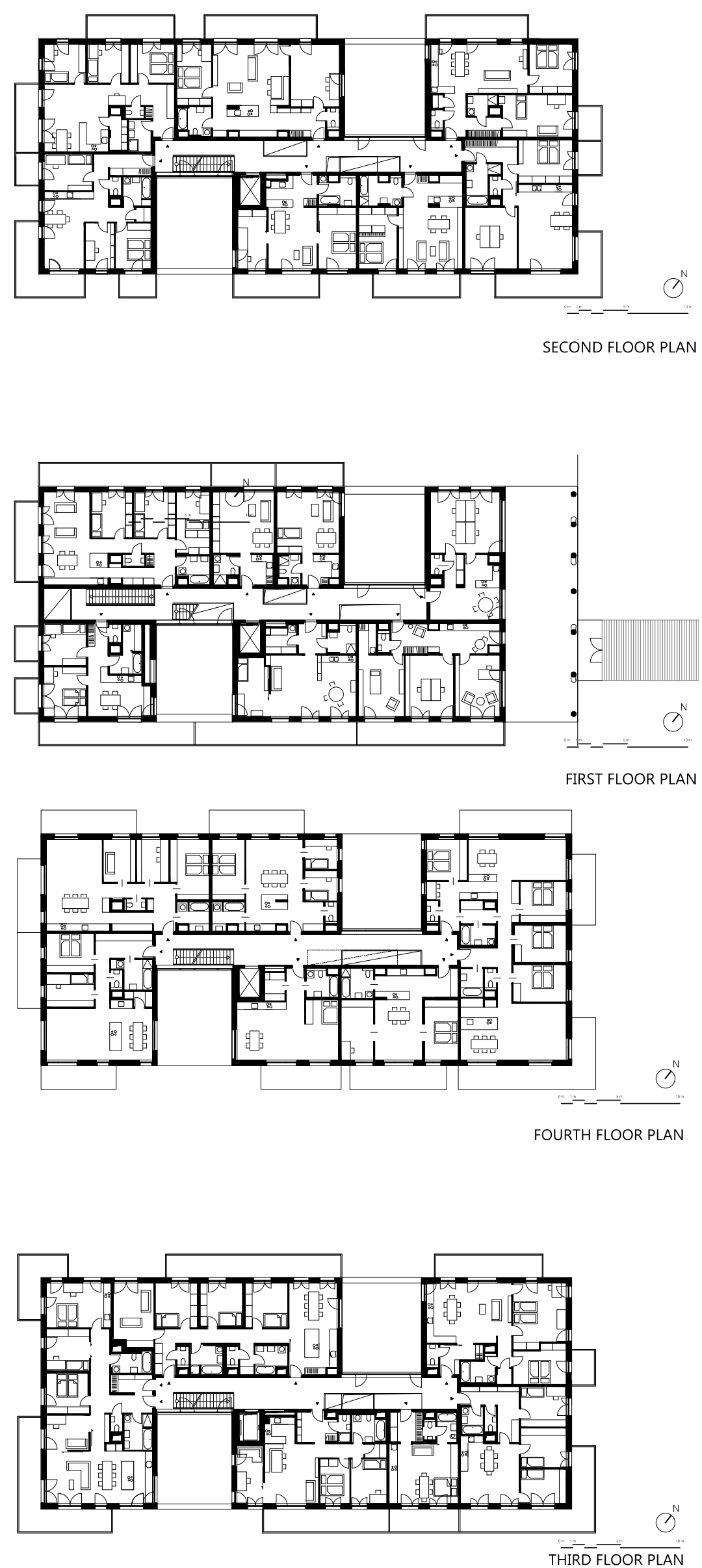

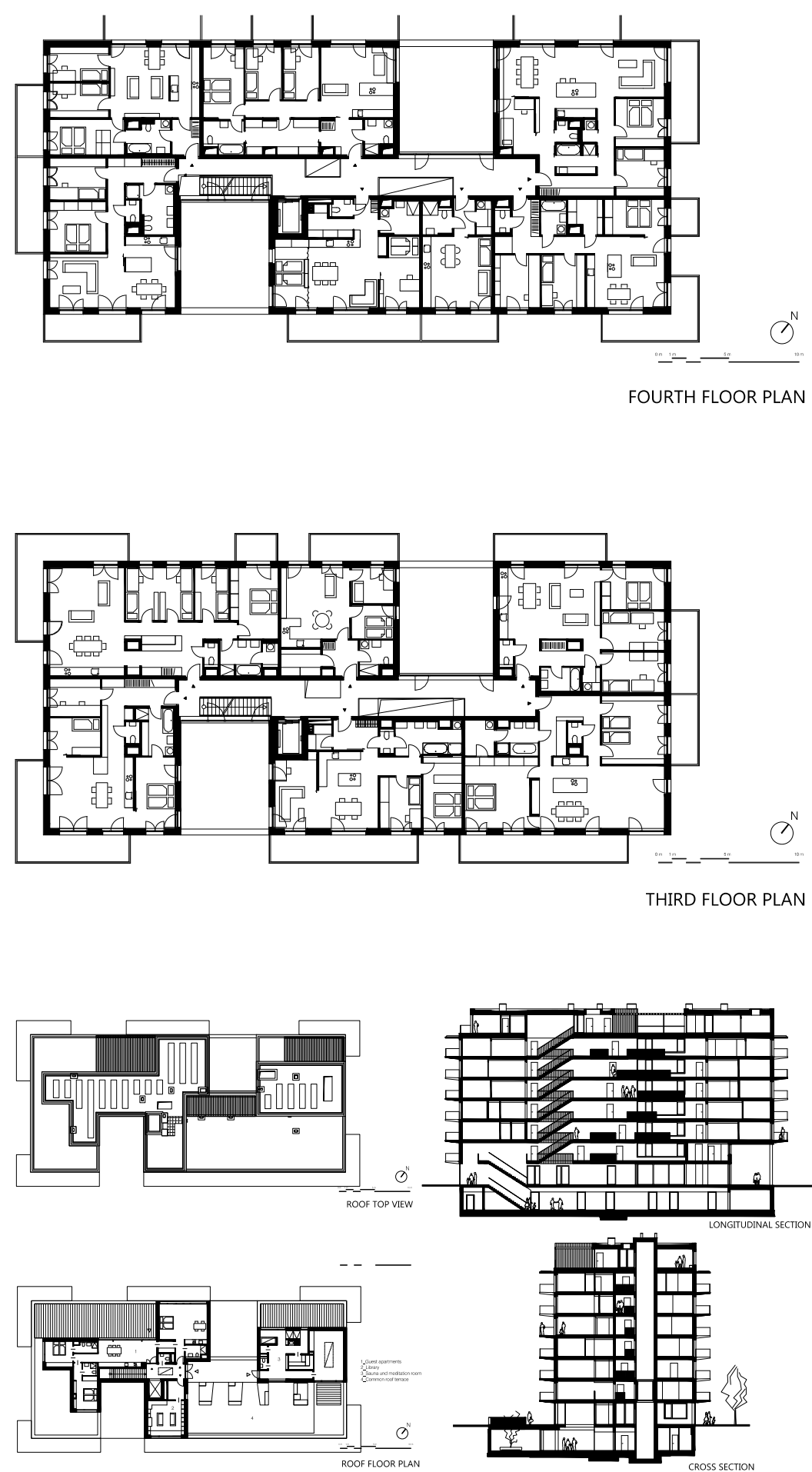

Figure 23. Roof plans and sections (Einszueins Arch. Office Documents)

\section{Children's Playground:}

Play spaces have a great significance to improve intelligence and brain growth and playing is an approach to education (Piaget, 1990). Besides, according to Freud, playing in childhood is the base for creative thinking (Freud, 1959). Therefore it is essential for living spaces to provide opportunities for play for for children and youth. 
The building has a small open playground that includes sandpit and swing (Figure 24). As it was mentioned before, the sunken courtyard also offers a creative building space for children. The Bednar Park in front of the building and other playgrounds of housing around the site also provide additional playing possibilities for the children of "Wohnen mit uns". Moreover, the indoor playground in the building is visible from other common rooms and therefore enhances the playing possibilities of the young inhabitants.

Figure 24. Playground (Leeb, 5/2014)

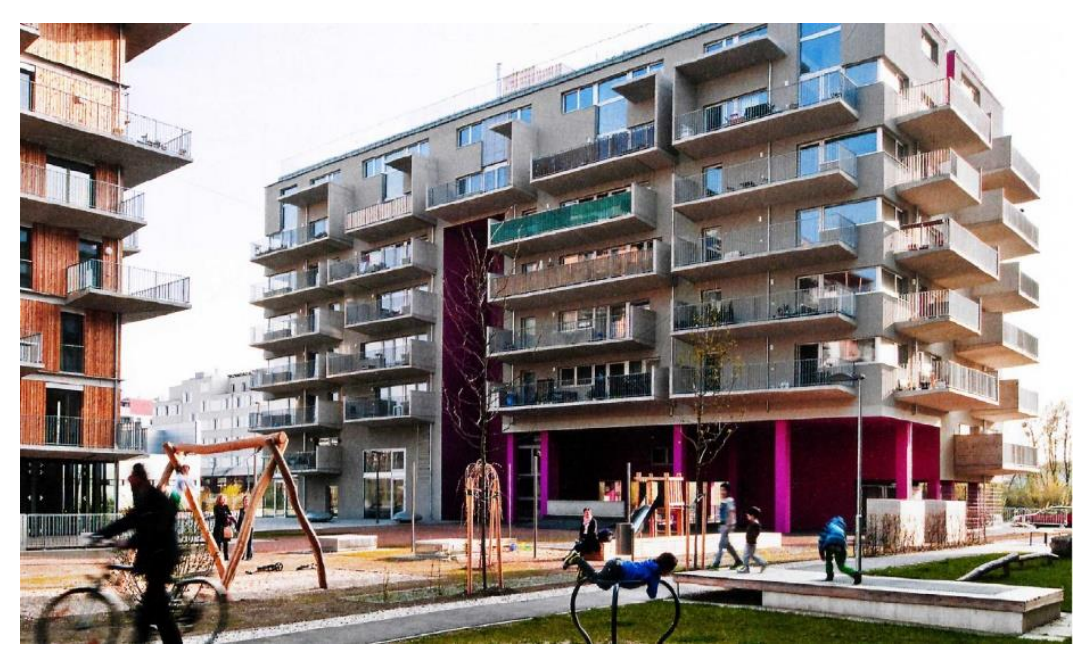

\section{Storage, Parking and Waste Services:}

Convenient car parking and waste services are positive attributes in housing. The underground garage is provided in the next building, "Wohnen mit Scharf" but due to the car-free (mobility) concept of the buliding "Wohnen mit uns", an essential aspect for the architects in the design phase to support the idea of sustainability, it has been developed a system of self-organised car sharing. In this system there are eight park places, which also includes a car parking area for disabled people. The architect Zilker says in the interview with the author that this system is sufficient to support the car needs of the inhabitants.

There is a wide bicycle-parking place for 116 bicycles near to the parking garage. Moreover, there are also rooms for baby buggies to support the daily life of families. Each dwelling also has storage rooms inside and outside of the dwellings.

\section{CONCLUSION}

This study has focused on the significance of social sustainability in residential areas. Indicators of this quality have been identified to provide the possibility of analysing and evaluating several housing projects.

The results were attained from the analysis of social sustainability through the developed framework; the project "Wohnen mit uns" 
proves a successful design and practice process. Participation, communication and integration are supported through several community rooms and the concept of car sharing are the most prominent aspects of the project in relation to the social sustainability. In addition to these aspects, the project offers various dwelling types and flexibility, which respond different requirements of the different types of families, and healthy open spaces and playgrounds, good storage possibilities, convenient building sizes in human scale and efficient layouts.

In conclusion, the findings show that the project is a demonstration project in terms of social quality and sustainability and quality of housing. With this better quality of housing projects, which improves social relations of people, a sustainable and more liveable future will be ensured.

The success of housing and sustainability today in Vienna, one of which is demonstrated in "Wohnen mit uns", is the product of their long-standing history of experiences, initiatives and policies as well as concept projects such as participatory housing (Kalfaoglu Hatipoglu, 2016a). Ottokar Uhl and Sargfabrik are the examples of participatory housing projects designed in the years 80s and 90s. These policies and experiences can shed the light on other countries as well as Turkey, as the positive affecting factors of architecture can be translated considering that all human in the world desire and deserve a liveable life.

With this overall aim, this study provides a helpful guideline through defining the criteria to evaluate social quality for the actors of new residential projects in countries such as Turkey. As intensive mass productions of housing have been built without a clear vision and social quality in Turkey (Tekeli, 2010). In addition, this successful demonstration project presents a respectable example of practice of these criteria to enable a better understanding of social sustainability, which improves housing projects designed for the middle class in Turkey. Built on the findings from the case study it is clear that successful housing implementations can be applied in Turkey if the building actors take more responsibility about human-centered planning, liveability and quality of life for all and take into consideration aforementioned guideline about social quality in housing. New and radical concepts supporting social quality should be derived to enhance housing towards a liveable life. The building policy of the municipalities should also support these kinds of projects with subsidies and motivations. Moreover, the desire and incorporation of the inhabitants for these kinds of the concepts is also an important factor for this social quality as we see the model in the background of the case study. 


\section{Acknowledgement}

This study was developed from the evaluation principals of social qualities in Doctoral Dissertation "Improving Turkish Housing Quality through Holistic Architecture: Assessment Framework, Guidelines, Lessons from Vienna" by Hatice Kalfaoglu Hatipoglu at Technical University of Vienna.

\section{REFERENCES}

Alexander, C. (1977). A Pattern Language: Towns Buildings Construction. New York: Oxford University Press.

Bayer, K. (2015a). Presentation Mobilität und Wohnen aus der Sicht der Nutzerinnen-Partizipatives Planen und Wohnen am Beispiel Wohnprojekt Wien. . Retrieved from https://www.bmvit.gv.at/innovation/mobilitaet/forschu ngsforum/ffm downloads/bayer partizipatives wohnpr ojekt.pdf

Bayer, K. (2015b). Turn on Architektur Festival 2015: vorträge nonstop im RadioKulturhaus. Vienna: Raum.Film Filmproduktion.

Brundtland, G. (Ed.) (1987). Our Common Future: The World Comission on Environment and Development. Oxford: Oxford University Press.

"Ein Weiter Schritt über Technische Werte Hinaus, Wohnhaus Wohnprojekt Wien, Wien Leopoldstadt." (2014) Magazin Staatspreis 2014 Architektur und Nachhaltigkeit. Vienna: Federal Ministry of Agriculture, Forestry, Environment and Water Management.

Freud, S. (1959). Creative Writers and Daydreaming (J. Strachey, Trans.). In J. Strachey (Ed.), The standard edition of the complete psychological works of Sigmund Freud (Vol. 9, pp. 141-153). London: Hogarth Press.

"Functionality". (n.d.). Merriam-Webster Dictionary.Retrieved May 10 2017, from www.merriamwebster.com/dictionary/functionality

Gehl, J. (1987). Life between Buildings: Using Public Space (J. Koch, Trans.). New York: Van Nostrand Reinhold Company.

Kalfaoglu Hatipoglu, H. (2016a). Austrian Sustainable Building Policy: Lessons for Turkey. International journal of Environmental Science and Development, 7(5).

Kalfaoglu Hatipoglu, H. (2016b). Improving Turkish Housing Quality through Holistic Architecture: Assessment Framework, Guidelines, Lessons from Vienna. (Doctoral dissertation), Technical University of Vienna, Vienna.

Kaltenbrunner, R. (2002). Auf dem Weg zum nachhaltigen Bauen: über die unscharfe Relation von Ökologie, Architektur und gesellschaftlichem Wandel. IzR- Informationen zur Raumentwicklung, 1/2, 1-10.

Leeb, F. (5/2014). Intercultural housing, Vienna- Achieving more together. Architektur.aktuell magazin, 410, 107.

Littig, B. a. G., E. (2005). Social Sustainability: A Catchword between Political Pragmatism and Social Theory. International Journal of Sustainable Development, 8, 72. 
Piaget, J. (1990). Dreams and Imitation in Childhood. NY: Norton Library.

Rosner, D. (2007). Sick Building Syndrome and the problem of uncertainty. Journal of Historical Med All Sci, 62(3), 376378.

Schönfeld, A. (2012). Einmal „Wohnen mit Scharf, bitte!“, Interkulturelles und gemeinschaftliches Wohnen am Nordbahnhofgelände Wien. Zement+Beton Magazin, 4, 23.

Tekeli, I. (2010). Konut Sorununu Konut Sunum Bicimleriyle Düsünmek. Istanbul: Dil Tarih Vakfi Yurt Yayinlari.

Van der Voordt, T. J. M. a. v. W. H. B. R. (2005). Architecture in Use: An introduction to the Programming, Design and Evaluation of Buildings. Oxford: Archiectural Press of Elsevier.

"Vienna voted the most livable city in the World for the eight time!"Retrieved May 10 2017, from https://www.wien.info/en/lifestyle-scene/most-livablecity.

Zilker, M. (2015). Turn-on Architektur Festival 2015: Vorträge nonstop im RadioKulturhaus. Vienna: Raum.Film Filmproduktion.

\section{Resume}

Hatice Kalfaoglu Hatipoglu works at Ankara Yildirim Beyazit University, Department of Architecture, as an Asst. Prof. She got her B. Sc. and MSc (as Dipl. Ing) degrees at Faculty of Architecture and Planning at Vienna University of Technology, Vienna, Austria in 2008. She also obtained her PhD degree in Architecture and Planning from Vienna University of Technology.

She worked as an intern in architecture offices Coop Himmelblau in Vienna and Mimarlar in Turkey. She worked as an architect and a designer in BG4 Architects, Zauhenberger Architecture Office and Espace Design \& Visualisation Company in Austria. Her current research interests are housing design quality and sustainability. 